\title{
Differences in effectiveness of guava leaf extract (psidium guajava linn) and lime water (citrus aurantifolia) as irrigation material of root canal as inhibitors of bacteria enterococcus faecalis (Laboratory of Microbiology Faculty of Pharmacy University of Muslim Indonesia (UMI) Makassar 2018)

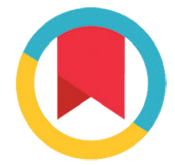 \\ CrossMark
}

\author{
Syamsiah Syam, Nur F. Arifin, Nurkhairah Y. Irkan*
}

\section{Abstract}

Objective: Analyze the differences in inhibition zone diameter between $60 \%$ guava leaf extract (psidium guajava linn.) and $100 \%$ lime juice (citrus aurantifolia) when inhibiting the growth of enterococcus faecalis bacteria.

Material and Methods: This study was a laboratory experimental method with post-test only control group design. Sampling with purposive sampling using 4 treatments and 5 repetitions. Statistical test used One-way ANOVA.

Results: The results of this study showed $60 \%$ guava leaf extract (Psidium guajava linn.) inhibited the growth of enterococcus faecalis bacteria with a diameter of inhibition zone of $11.75 \pm 0.680$ while $100 \%$ lime juice (citrus aurantifolia) had a a diameter of inhibition zone of $20.67 \pm 2.655 \mathrm{~mm}$, and based on statistical test determined $p=0.0046<p=0.05$.

Conclusion: The alternative hypothesis of this study was accepted and the results of this study indicate that there was a difference of effectiveness between $60 \%$ guava leaf extract (psidium guajava linn.) and 100\% lime juice (citrus aurantifolia) extract as root canal irrigation material that can inhibit bacterial growth of enterococcus faecalis.
Department of Endodontics, Faculty of Dentistry, Indonesian Muslim University, Makassar, Indonesia
*Corresponding to:

Nurkhairah Y. Irkan, Department of Endodontics, Faculty of Dentistry, Indonesian Muslim University, Makassar, Indonesia nurkhairah.yustisi@gmail.com

Received: 29 July 2018

Revised: 20 ctober 2018

Accepted: 7 November 2018

Available 0nline 1 December 2018

Keywords: Root canal irrigation, Guava leaf extraxt, Lime juice, Enterococcus faecalis

Cite this Article: Syam S, Arifin NF, Irkan NY. 2018. Differences in effectiveness of guava leaf extract (psidium guajava linn) and lime water (citrus aurantifolia) as irrigation material of root canal as inhibitors of bacteria enterococcus faecalis (Laboratory of Microbiology Faculty of Pharmacy University of Muslim Indonesia (UMI) Makassar 2018). Journal of Dentomaxillofacial Science 3(3): 156-161. D0I: 10.15562/jdmfs.v3i3.780

\section{Introduction}

Microorganisms could enter the root canal through multiple routes. Generally, the main entrance of microorganisms into the pulp was in the presence of dental caries. Microorganisms might also enter the pulp cavity due to mechanical or traumatic injury through the gingival sulcus and bloodstream. ${ }^{1}$

Several studies had proven that nearly $90 \%$ of infections in root canals were bacteria. One of which is a species of gram-positive bacteria known as enterococcus faecalis. Studies of bacterial and molecular cultures confirm that enterococcus faecalis is one of the most prevalent bacteria found in post-root canal root canals that fail. The high resistance of enterococcus faecalis is caused by, among others reasons, the ability of enterococcus faecalis to survive in unfavourable environments. ${ }^{2-4}$

Infected root ducts due to microorganisms play an important role in the occurrence of necrosis of the dental pulp and the development of periapical disorders such as abscesses, granulomas and cysts. Therefore, root canal treatment should be aimed at eliminating or reducing the microbial population and biomechanically removing the necrotic tissue in the root canal system that can act as a microbial growth medium and preventing re-infection by closing the chamber., ${ }^{4,5}$

Root canal treatment can be divided into 3 main stages of root canal biomechanical preparation or cleaned and shaping, disinfection and obturation of root canals. Irrigation is one of the important stages in supporting the success of root canal treatment, since irrigation facilitates the removal of necrotic tissue, microorganisms, and dentine debris from infected root canals. An ideal origin should be non-toxic, inexpensive, and easy to use..$^{6-8}$

Currently there were several commonly used irrigation materials, namely sodium hypochlorite $(\mathrm{NaOCl})$, ethylenediaminetetraacetic acid (EDTA) solution, mixture of tetracycline, an acid and a detergent (MTAD), chlorhexidine, and iodine potassium iodide (IPI). However, the most frequently used is $0.5 \%-5.25 \% \mathrm{NaOCl}$. This is because $\mathrm{NaOCl}$ is considered to be quite effective as an irrigation solution and is considered to represent the ideal 
conditions of the irrigation solution compared to other irrigation solutions. In addition, several in vitro studies showed that a $5.25 \% \mathrm{NaOCl}$ solution was able to kill Enterococcus faecalis within 30 seconds. However, $\mathrm{NaOCl}$ can create a disruption of the periradicular tissue causing pain, swelling and ulceration. One disadvantage of $\mathrm{NaOCl}$ is that it is unable to make good contact with all tissues and not all bacteria in the root canal can be removed. ${ }^{7,2}$

The use of materials derived from nature can be an option as an alternative to root canal irrigation materials because some of these materials can be inhibit the growth (bacteriostatic) or kill bacteria (bactericide). The use of traditional medicines was considered to have fewer side effects compared to drugs derived from chemicals and ultimately, the price is more affordable. ${ }^{8}$

Guava plants (Psidium guajava linn.) are wellknown by the people of North Sulawesi and often used to treat dengue fever by means of the juice, but the guava leaf was rarely used as a medicinal plant when the leaves have been proven to treat various diseases such as diarrhoea, dysentery, dengue fever, swollen gums, canker sores, heart and diabetes. Guava leaves can be used as anti-inflammatory and hemostatic remedies. Guava leaf contains active ingredients, including antibacterial tannins (precipitating proteins from bacteria), quercetin, polyphe nolate, quinone, saponins, alkaloids, and flavonoids that can inhibit bacterial growth, leukocyanidin, essential oils, malic acid, resin and oxalic acid. ${ }^{9}$

Another natural plant that has developed in the field of Dentistry as an alternative substance of root canal irrigation is lime (Citrus aurantifolia). Lime has antimicrobial activity that is effective against gram-positive and gram-negative bacteria. The advantages of using lime juice as an antibacterial is that it is easy to obtain. The acid content in lime juice serve as a source of coagulant. In addition, citric acid compounds contained in lemon juice can prevent microbial growth. ${ }^{2}$

Based on research at Muhammadiyah University of Yogyakarta, that $60 \%$ guava leaf extract is more effective than other concentration in inhibiting growth of Enterococcus faecalis bacteria. Another study at Lambung Mangkurat University stated that $100 \%$ lime juice is more effective than other concentrations in inhibiting the growth of enterococcus faecalis bacteria. Therefore, the researchers are interested in determining the effectiveness of $60 \%$ guava leaf extract and 100\% lime juiceas irrigation agents of Enterococcus faecalis inhibitor root canal.

\section{Material and Methods}

This research used laboratory experimental method with post-test only control design research form. The type of research conducted was true experimental laboratory. In this research method, the sampling technique used was purposive sampling, using 4 treatments with 5 times repetition obtained from the calculation using the formula Lukito.

The research tools used in this research were stationery, autoclave, incubator, split $10 \mathrm{~mL}, 5 \mathrm{~mL}$ and $1 \mathrm{~mL}$, paper disk, analytical scales, Petri dish, sterilizer (oven), stirring bar, reaction cylinder, spoon horn (flatware), round oceans, beaker, spiral light, tweezers, slipper, plastic warp, gloves, aluminum foil, erlenmeyer tube, buchner mouthpiece coated filter paper, label paper, mask and vial bottle.

The ingredients used in this study were bacterium enterococcus faecalis, guava leaf, lime, aquades, $2 \%$ chlorhexidine, Mueller Hinton Agar (MHA), 96\% ethanol and spirits.

The tools used were washed thoroughly and then dried, for sterilized glassware using an oven at $180^{\circ} \mathrm{C}$ for 2 hours. Heavy-scale and non-heatresistant glassware and plastics was sterilized in an autoclave at $121^{\circ} \mathrm{C}$ for 15 minutes.

Gauva leaves were collected while they were still fresh green and then the guava leaf was washed, dried, cut into small pieces and put into oven with temperature $500^{\circ} \mathrm{C}$. Guava leaf was said to be dry if it appeared brownish. A total of $200 \mathrm{~g}$ of guava leaf was weighed and dissolved with $2000 \mathrm{~mL}$ of $96 \%$ ethanol for 24 hours. The result obtained was filtered using a Buchner funnel, after which it was evaporated from the rest of the solvent with a threehour evaporator with a temperature of $70^{\circ} \mathrm{C}$.

The pure extract obtained was placed into a $40^{\circ} \mathrm{C}$ oven at for two hours then poured into a sterile glass bottle, covered and stored in a refrigerator.

The weighted guava leaf extract was then dissolved with $1 \mathrm{~mL}$ of aquades to obtain a $60 \%$ concentration. The resulting dilution of guava leaf extract was stored in a vial bottle and labelled.

Limes were washed with clean water and rinsed with $96 \%$ ethanol then cut into 2 parts. The limes were then juiced into a $100 \mathrm{~mL}$ into the Erlenmeyer flask and filtered using filter paper and then re-filtered using a $0.2 \mu \mathrm{m}$ membrane filter. The $100 \%$ lime juice was covered with sterile aluminum foil and stored at $4^{\circ} \mathrm{C}$ until use.

MHA (3.4 grams) was dissolved with $100 \mathrm{~mL}$ of aquades in an Erlenmeyer flask and covered with gauze and wrapped in paper. The medium was sterilized in an autoclave at $121^{\circ} \mathrm{C}$. for 25 minutes. Next, use split to insert $10 \mathrm{~mL}$ of medium into a sterile vial bottle. Take 1 ose of bacteria then insert into vial containing medium then homogenize. Pour into a Petri dish and leave it to solidify. Where the bottom of the petri dish was divided according 
to the number of paper disks to be assigned to determine the area boundary of each treatment on the MHA.

After the medium was solidified, the paper disk was inserted into $60 \%$ guava leaf extract using tweezers and then placed on the surface of the media which is cultured enterococcus faecalis. The other surfaces of the media are given different treatments, ie paper disks that have been inserted into $100 \%$ lime juice, aquades and also $2 \%$ Chlorhexidine (CHX) using tweezers. They were incubated at $37^{\circ} \mathrm{C}$ for 24 hours.

Table 1 Inhibitory zone diameter of $60 \%$ guava leaf extract, positive control $(\mathrm{K}+)$ and negative control (K-) inhibiting the growth of enterococcus faecalis bacteria

\begin{tabular}{|c|c|c|c|c|c|c|}
\hline \multirow[b]{2}{*}{ Replication } & \multicolumn{3}{|c|}{$\begin{array}{c}\text { Cashew Leaf Extract } \\
\text { Concentration } 60 \% \\
(\mathrm{~mm})\end{array}$} & \multicolumn{3}{|c|}{$\begin{array}{c}\text { Control } \\
(\mathrm{mm})\end{array}$} \\
\hline & & Mean \pm SD & K- & Mean \pm SD & $\mathbf{K}+$ & Mean \pm SD \\
\hline 1. & 12.00 & \multirow{5}{*}{$\begin{array}{c}11.75 \pm \\
0.680\end{array}$} & 0.00 & \multirow{5}{*}{$\begin{array}{c}0.00 \pm \\
0.000\end{array}$} & 25.70 & \multirow{5}{*}{$\begin{array}{c}31.91 \pm \\
6.414\end{array}$} \\
\hline 2. & 11.09 & & 0.00 & & 32.19 & \\
\hline 3. & 12.60 & & 0.00 & & 41.08 & \\
\hline 4. & 12.04 & & 0.00 & & 26.02 & \\
\hline 5. & 11.01 & & 0.00 & & 34.58 & \\
\hline
\end{tabular}

Table 2 Inhibition zone diameter of $\mathbf{1 0 0 \%}$ lime juice, the positive control $(\mathrm{K}+)$ and the negative control (K-) on the growth of enterococcus faecalis bacteria

\begin{tabular}{|c|c|c|c|c|c|c|}
\hline \multirow[b]{2}{*}{ Replication } & \multicolumn{3}{|c|}{$\begin{array}{l}\text { Lime juice (Citrus } \\
\text { aurantifolia) } \\
\text { concentration } \\
100 \%(\mathrm{~mm})\end{array}$} & \multicolumn{3}{|c|}{$\begin{array}{c}\text { Control } \\
(\mathrm{mm})\end{array}$} \\
\hline & & Mean \pm SD & K- & Mean \pm SD & $\mathbf{K}+$ & Mean \pm SD \\
\hline 1. & 19.05 & & 0.00 & & 25.70 & \\
\hline 2. & 17.82 & & 0.00 & & 32.19 & \\
\hline 3. & 24.84 & $20.67 \pm 2.655$ & 0.00 & $0.00 \pm 0.000$ & 41.08 & $31.91 \pm 6.414$ \\
\hline 4. & 20.87 & & 0.00 & & 26.02 & \\
\hline 5. & 20.79 & & 0.00 & & 34.58 & \\
\hline
\end{tabular}

Table 3 Differences in inhibition zone diameter of $60 \%$ guava leaf extract, $100 \%$ lime juice, the positive control $(\mathrm{K}+)$ and the negative control (K-) inhibiting the growth of enterococcus faecalis bacteria

\begin{tabular}{|c|c|c|c|c|}
\hline Group & Comparison & $\begin{array}{c}\text { Mean } \\
\text { Difference }\end{array}$ & Std. Error & $\mathbf{p}$ \\
\hline \multirow{3}{*}{$\begin{array}{l}60 \% \text { Guava leaf } \\
\text { extract }\end{array}$} & 100\% Lime juice & $-8.92600^{*}$ & 2.20564 & $0.0046^{\star}$ \\
\hline & $\mathrm{K}+(\mathrm{CHX})$ & $-20.16600^{*}$ & 2.20564 & $0.0000^{*}$ \\
\hline & K- (Aquades) & $11.74800^{\star}$ & 2.20564 & $0.0000^{\star}$ \\
\hline \multirow[t]{2}{*}{ 100\% Lime juice } & $\mathrm{K}+(\mathrm{CHX})$ & $-11.24000^{*}$ & 2.20564 & $0.0010^{\star}$ \\
\hline & K- (Aquades) & $20.67400^{*}$ & 2.20564 & $0.0000^{\star}$ \\
\hline $\mathrm{K}+(\mathrm{CHX})$ & K- (Aquades) & $31.91400^{*}$ & 2.20564 & $0.0000^{*}$ \\
\hline
\end{tabular}

The inhibitory power was based on the measurement of inhibition zone diameter (clear zone or clear area without microorganism growth) formed around the paper disk. The measurement used a digital threshold expressed in millimetres $(\mathrm{mm})$.

\section{Results}

Inhibition zones were measured with the inhibitory test using $60 \%$ guava leaf extract, sterile aquades as a negative control and $2 \% \mathrm{CHX}$ as a positive control against the growth of enterococcus faecalis bacteria using five replicates on each group. The results obtained are listed in table 1.

Table 1 shows an inhibition zone has been formed in the medium around the paper disk given $60 \%$ guava leaf extract and $2 \%$ chlorhexidine. The results of the measurements in the table above show that the largest inhibition zone was observed in $60 \%$ guava leaf extracton replication 3 of $12.60 \mathrm{~mm}$ and the smallest inhibition zone is formed on replication 5 of $11.01 \mathrm{~mm}$. The mean value of five replications of $60 \%$ guava leaf extract was $11.75 \pm$ $0.680 \mathrm{~mm}$. The positive control showed the largest inhibition zone in replication 3 of $41.08 \mathrm{~mm}$ and the smallest inhibition zone in replication 1 of $25.70 \mathrm{~mm}$. The mean value of the five replicates of $2 \%$ chlorhexidine was $31.91 \pm 6.414 \mathrm{~mm}$. In the negative control, there was no zone of inhibition around the paper disk.

The inhibition zone was measured with the inhibitory test using $100 \%$ lime juice, $2 \% \mathrm{CHX}$ as a positive control and aquades as a negative control on the growth of enterococcus faecalis bacteria by using five replications on each for each group. The results obtained are listed in table 2.

Table 2 shows that inhibition zones have been formed in the medium around the paper disk given $100 \%$ lime juice and 2\% chlorhexidine against the growth of enterococcus faecalis bacteria. The results showed that the largest inhibition zone in $100 \%$ lime juice was replication 3 of $24.84 \mathrm{~mm}$ and the smallest inhibition zone was replication 2 of 17.82. The average value of the five replicates of $100 \%$ lime juice was $20.67 \pm 2.655 \mathrm{~mm}$.

The inhibition zone was measured with the inhibitory test using $60 \%$ guava leaf extract, $100 \%$ lime juice, aquades as negative control and 2\% chlorhexidine as a positive control on the growth of Enterococcus faecalis bacteria by doing each of five replications, the result of difference of diameter of inhibition zone according to table 3 .

Table 3 shows the difference in inhibition zone diameter between $60 \%$ guava leaf extract, $100 \%$ lime juice, as well as a positive control and 
negative control on the growth of enterococcus faecalis bacteria. Based on the results of post hoc multiple comparisons statistical test or further test, it was found that the difference in inhibition zone diameter between $60 \%$ guava leaf extract and $100 \%$ lime juice was $-8.926 \mathrm{~mm}$ with a statistically significant p-value of 0.0046 . The positive control and $60 \%$ guava leaf extract had a difference

$20.166 \mathrm{~mm}$ and also had a statistically significant p-value of 0.0000 . The $60 \%$ guava leaf extractand negative control differed by $11.748 \mathrm{~mm}$ with had a statistically significant $p$-value of 0.0000 . The $100 \%$ lime juice and positive control differed by $11.240 \mathrm{~mm}$ and had a statistically significant p-value of 0.0010 , The $100 \%$ lime juice and negative control differed by $20.674 \mathrm{~mm}$ and had a statistically significant p-value of 0.0000 . Finally, the positive control and the negative control differed by $31.914 \mathrm{~mm}$ and had a statistically significant p-value of 0.0000 .

\section{Discussion}

Based on the results of the research, the presence of inhibition zones, or clear zones, formed on the medium around the paper disk containing 60\% guava leaf extractand $2 \%$ CHX. The diameter of the inhibition zone formed showed that the presence of antibacterial activity in $60 \%$ guava leaf extract and 2\% CHX against the growth of enterococcus faecalis bacteria. In the agar medium given a paper disk containing only sterile aquades as a negative control did not form a clear inhibition zone around the paper disk. This was in line with a study at Muhammadiyah University of Yogyakarta that stated $60 \%$ guava leaf extract inhibits the growth of enterococcus faecalis bacteria. ${ }^{10}$

Based on this research, zones of inhibition or clear zones formed on the medium around the paper disk containing 100\% lime juice. The diameter of the inhibition zone formed shows that the antibacterial activity of $100 \%$ lime juice against the growth of enterococcus faecalis bacteria. This was inline with research at Lambung Mangkurat University stating that $100 \%$ lime juiceis effective in inhibiting the growth of enterococcus faecalis bacteria $^{2}$

Looking at the average diameter of inhibition zones, the positive control group produced the largest inhibition zone diameters of $31.91 \pm 6.414$ $\mathrm{mm}$ compared to the inhibition zone diameters of $60 \%$ guava leaf extract $(11.75 \pm 0.680 \mathrm{~mm})$ and $100 \%$ lime juice $(20.67 \pm 2.655 \mathrm{~mm})$. This shows that $2 \% \mathrm{CHX}$ has strong antibacterial activity when compared to $60 \%$ guava leaf extract and $100 \%$ lime juice.
The category of inhibition zone inhibition assessment can be drawn from the measurements of diameters classified as no inhibition zone (0 $\mathrm{mm})$, weak $(<5 \mathrm{~mm})$, moderate $(5-10 \mathrm{~mm})$, strong $(11-20 \mathrm{~mm})$ and very strong $(>20 \mathrm{~mm})$. Based on the above criteria, the zone of inhibition formed around the paper disk containing 2\% chlorhexidine as positive control can be categorized as very strong, the $60 \%$ guava leaf extract can be categorized as strong, and the $100 \%$ lime juicecan be categorized as very strong when inhibiting the growth of enterococcus faecalis bacteria. The negative control (sterile aquades) showed no inhibition zone diameter is formed, so it can be said that the negative controls used do not have antibacterial power in inhibiting the growth of enterococcus faecalis bacteria. ${ }^{11}$

Based on the research results obtained, the data has homogeneous research results. Homogeneity was tested using the Levene's Test. Research result are said to be homogeneous if homogeneity test results have a significance value of $p>0.05$. In this study, the normality test was done using the ShapiroWilk test because the number of samples was less than 50 samples. Normality test results showed that the test bacteria group had a significance value of $>0.05$, therefore the data of the research results were said to be of normal distribution.

Based on Levene's test homogeneity test and Shapiro-Wilk normality and then tested using One Way ANOVA analysis. The results showed significance value $\mathrm{p}=0.000(\mathrm{p}<0.05)$. This means there were significant differences. Furthermore, the post-hoc multiple comparisons test was used to see whether there was a difference or not between each treatment group.

The post-hoc multiple comparisons test found that there are significant differences seen in all groups. The difference in mean diameter of the largest inhibition zone exists between $2 \%$ chlorhexidine as a positive control with sterile aquades as a negative control and the difference in mean diameter of the smallest inhibition zone is between $100 \%$ lime juice and $60 \%$ leaf extract. This difference is due to the different content of active substances present in each group.

The greatest inhibition zone was found in $2 \%$ chlorhexidine because the active ingredients are bactericidal (kill bacteria). CHX is often used in endodontic treatment and it is recommended as a root canal irrigation solution but not a major irrigation material because it is unable to dissolve the remnants of necrotic tissue, it is less effective against gram-negative bacteria, and it has side effects such as toxicity. The use of natural derived ingredients, such as guava leaf extract and lime juice, can be an option 
as an alternative to root canal irrigation materials. In addition to the fact that some of these ingredients can inhibit growth (bacteriostatic) and kill bacteria (bactericidal), these ingredients are also considered to have less side effects compared to chemicals, and are more affordable. ${ }^{7,8}$

The second largest inhibition diameter after $2 \%$ CHX was 100\% lime juice. Lime juice had a difference in mean diameter of the greater inhibition zone compared to guava leaf extract. Both treatments contain flavonoids and other active substances that can act as antibacterials. However, lime juice contains citric acid causing a low $\mathrm{pH}$ (2). At that $\mathrm{pH}$, the bacteria enterococcus faecalis is unable to grow because the bacteria prefers a $\mathrm{pH}$ environment around 4-11. Changes in $\mathrm{pH}$ in the bacterial cell will inhibit the process of sending amino acids from RNA that inhibits bacterial growth. ${ }^{12}$

The antibacterial ability of lime juice and guava leaf extract has been proven in various previous studies. A study conducted by Lauma. ${ }^{13}$ said that lime juice has an antibacterial effect on the growth of colonies of staphylococcus aureus characterized by an inhibitory zone formed. This is due to the presence of antibacterial active compounds in the lime juice obtained from the chemical content contained therein, such as essential oils, capable of inhibiting the growth of staphylococcus aureus bacteria. The study conducted by Berlian. ${ }^{14}$ has similarities with this study which states that lime juice has an antibacterial effect, indicated by the zone of inhibition that occurs on the growth of escherichia coli bacteria. Inhibition zones occur due to the presence of antibacterial active compounds such as citric acid, flavonoids, and saponins contained in lime juice that are able to inhibit the growth of microbes, such as bacteria escherichia coli. ${ }^{13,14}$

Guava leaf extract has an antibacterial effect on the growth of lactobacillus acidopilus colonies characterized by formation of inhibition zones. Guava leaf extract can inhibit the growth of bacteria because contains active compounds, such as flavonoids, tannins and saponins. This research has similarities with previous studies that state that the guava leaf has an antibacterial effect, indicated by the zone of inhibition formed against the growth of staphylococcus aureus bacteria. The factors that affect the ability of guava leaf extract that is bacteriostatic and bactericidal that contain active compounds saponin, tannin, triterpenoid and flavonoids. ${ }^{15,16}$

\section{Conclusion}

Based on the results of research conducted by researchers, it can be concluded: $60 \%$ guava leaf extract (psidium guajava Linn.) has an inhibition zone diameter of $11.75 \pm 0.68 \mathrm{~mm}$ inhibiting the growth of enterococcus faecalis bacteria, $100 \%$ lime juice (citrus aurantifolia) has an inhibition zone diameter of $20.67 \pm 2.65 \mathrm{~mm}$ inhibiting the growth of enterococcus faecalis bacteria, the difference of inhibition zone diameter between $60 \%$ guava leaf extract (psidium guajava linn.) with $100 \%$ lime juice (citrus aurantifolia) of $-8.926 \mathrm{~mm}$ in inhibiting growth of Enterococcus faecalis bacteria with p-value $=$ $0.046<\alpha=0.05$.

\section{Acknowledgment}

Laboratory of Microbiology Faculty of Pharmacy, Indonesian Muslim University for providing facilities required for the successful completion of the research work.

\section{Conflict of Interest}

The authors report no conflict of interest.

\section{References}

1. Garg N, Garg A. Textbook of endodontics. 2nd ed. New Delhi: Jaypee; 2010. p. 46.

2. Ramadhinta et al. Uji efektifitas antibakteri air perasan jeruk nipis (Citrus aurantifolia) sebagai bahan irigasi saluran akar alami terhadap pertumbuhan enterococcus faecalis in vitro. Dent 2016;1: 124-128.

3. Sari AN, Untara TE. Root canal Retreatment menggunakan Kombinasi Kalsium Hidroksida dan Chlorhexidine sebagai Medikamen Intra Kanal Insisivus Sentral Kiri Maksila. Maj Ked GI 2014;21: 165-170.

4. Santoso ML. Konsentrasi hambat minimum larutan propolis terhadap bakteri Enterococcus faecalis. J PDGI 2012;61: 96-101.

5. Dewiyani S. Perawatan endodontik pada kasus periodontitis apikalis kronis (endodontic treatment on chronis apical periodontitis case). J PDGI 2014;63: 99-103.

6. Pasril Y, Yuliasanti A. Daya antibakteri ekstrak daun sirih merah (piper crocatum) terhadap bakteri Enterococcus faecalis sebagai bahan medikamen saluran akar, dengan metode dilusi. IDJ 2014;3: 88-95.

7. Tanumihardja M. Larutan Irigasi Saluran Akar. J Dentomaxillofac Sci 2010;9: 108-115.

8. Noventi W, Carolia N. Potensi ekstrak daun sirih hijau (piper betle 1.) sebagai alternatif terapi acne vulgaris. Major 2015;5: 140-145.

9. Tampedje AAD. Uji efek antibakteri ekstrak daun jambu biji (Psidium guajava linn.) terhadap pertumbuhan koloni strepptococcus mutans. J Ilmiah Farmasi-UNSRAT 2016;5: 222-228.

10. Sofiani E, Mareta DA. Perbedaan daya antibakteri antara klorheksidin diglukonat $2 \%$ dan ekstrak daun jambu biji (Psidium guajava linn) berbagai konsentrasi (tinjauan terhadap Enterococcus faecalis). IDJ 2014;3: 30-40.

11. Putra RED. Uji daya hambat perasan buah jeruk purut Citrus hyrix terhadap bakteri staphylococcus aureus secara in vitro. J Ilmiah Farmasi-UNSRAT 2017;6: 62-67.

12. Razak A. Uji daya hambat air perasan buah jeruk nipis (Citrus aurantifoolia s.) terhadap pertumbuhan bakteri staphylococcus aureus secara in vitro. J Kesehatan Andalas 2013;2: 5-8. 
13. Lauma SW. Uji efektifitas perasan air jeruk nipis (Citrus aurantifolia s) terhadap pertumbuhan bakteri staphylococcus aureus secara in vitro. J Ilmiah Farmasi-UNSRAT 2015;4: 9-14.

14. Berlian Z. Penggunaan perasan jeruk nipis (Citrus aurantifolia) dalam menghambat bakteri escherichia coli pada bahan pangan. J Bioil 2016;2: 51-58.

15. Misrulloh A. Uji daya hambat ekstrak daun jambu biji putih dan merah terhadap pertumbuhan bakteri karies gigi (lactobacillus acidophilus). Prosiding SNST 2017;8: $12-16$.
16. Minasari. Efektivitas ekstrak daun jambu biji buah putih terhadap pertumbuhan staphylococcus aureus dari abses. Makassar Dent J 2016;5: 34-39.

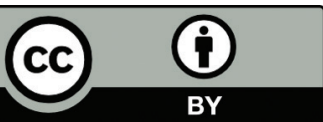

This work is licensed under a Creative Commons Attribution 